\author{
Katarzyna Maciejewska-Mieszkowska \\ Uniwersytet Warmińsko-Mazurski w Olsztynie \\ ORCID: 0000-0003-1623-8788
}

\title{
Telewizja jako aktor polityczny w ocenie społecznej Polaków
}

\begin{abstract}
Streszczenie
Telewizja traktowana jako jeden z aktorów politycznych podlega ocenie społecznej w zakresie jej wiarygodności i zaufania. W przypadku polskich mediów audiowizualnych wieloletnie badania sondażowe prowadzone w tym zakresie wykazują, że w ciągu ostatnich kilku lat zaszły zasadnicze zmiany w postrzeganiu przekazów telewizyjnych przez Polaków. Tendencję tę należy łączyć między innymi z dynamicznymi przeobrażeniami polskiej sceny politycznej oraz kształtującymi się preferencjami politycznymi odbiorców. Publikacja ma na celu ukazanie zaistniałych zmian w ocenie telewizji z uwzględnieniem stosunku Polaków do rzeczywistości politycznej oraz preferencji w zakresie korzystania z określonych źródeł informacji.
\end{abstract}

Słowa kluczowe: telewizja, aktor polityczny, ocena społeczna.

Television as a political actor in the social assessment by Poles

Abstract

Television, treated as one of political actors, is subject to social evaluation in terms of its credibility and trust. In the case of Polish audiovisual media, many years of surveys in the field show that in the last few years there have been fundamental changes in the perception of television broadcasts by Poles. This tendency should be associated with the dynamic transformations of the Polish political scene and the shaping of political preferences of the public. This publication aims to show changes in the assessment of television, taking into account the attitude of Poles towards political reality and their preferences in the use of specific sources of information.

Keywords: television, political actor, social assessment.

\section{Wprowadzenie}

Rodzaj, charakter i specyfika relacji między telewizją a polityką jest zagadnieniem analizowanym w szerokiej perspektywie badauczej. Poświęcone są mu zarówno rozważania teoretyczne, jak i badania empiryczne, z których wynika, że upłyu przekazów telewizyjnych na rzeczywistość polityczną oraz postawy i poglądy odbiorców 
jest niewątpliwy ${ }^{1}$. Dyskusyjne są natomiast skala i zakres tego wpływu, zwłaszcza w kontekście dynamicznego rozwoju internetu i nowych technologii komunikacyjnych². Nie zmienia to jednak faktu, na który zwraca uwagę Hans M. Kepplinger, że

dopiero telewizja spowodowała, że część społeczeństwa, która dotąd nie interesowała się bliżej polityką, teraz zaczęła stykać się z nią mimochodem i stworzyła podstawę dla przynajmniej powierzchownego zainteresowania. Gruntownie zmieniło to charakter komunikacji politycznej. Skutkiem była wizualizacja wydarzeń politycznych, która wzmocniła znaczenie prezencji, sposobu mówienia i zachowania niewerbalnego polityków³ ${ }^{3}$.

Należy także podkreślić, że pomimo uzrastającej rangi internetu jako źródła informacji ${ }^{4}$ dla większości Polaków to ułaśnie telewizja pozostaje podstawowym nośnikiem wiedzy o wydarzeniach w kraju i na świecie. W ankietach przeprowadzonych na zlecenie Centrum Badania Opinii Społecznej (CBOS) w 2019 roku pogląd taki wyraziło 58\% badanych Polaków ${ }^{5}$.

${ }_{1}$ Zob. m.in.: P. Bourdieu, O telewizji. Panowanie dziennikarstwa, przeł. K. Sztandar-Sztanderska, A. Ziółkouska, Wydawnictwo Naukowe PWN, Warszawa 2009; S.A. Hellweg, M. Pfau, S.R. Brydon, Televised Presidential Debates: Advocacy in Contemporary America, Praeger Publishers, New York 1992; Television and the Public Interest. Vulnerable Values in West European Broadcasting, red. J.G. Blumler, SAGE Publications, London 1992; Television News Research: Recent European Approaches and Findings, red. K. Renckstorf, D. McQuail, N. Jankouski, Quintessence Publishing Deutschland, Berlin 2001; M. Briggs, Telewizja i jej odbiorcy $w$ życiu codziennym, przeł. B. Radwan, Wydawnictuo Uniwersytetu Jagiellońskiego, Kraków 2012; B. Dobek-Ostrouska, Polski system medialny na rozdrożu. Media w polityce, polityka w mediach, Wydawnictuo Uniwersytetu Wrocłauskiego, Wrocław 2011; A. Jaskiernia, Od telewizji masowej do Netfliksa. Telewizja $w$ Stanach Zjednoczonych w epoce cyfrowej, Oficyna Wydawnicza ASPRA-JR, Warszawa 2016; B. Ociepka, Dla kogo telewizja? Model publiczny w postkomunistycznej Europie Środkowej, Wydawnictwo Uniwersytetu Wrocłauskiego, Wrocław 2003; K.T. Toeplitz, Dokąd prowadza nas media, Wydawnictuo Iskry, Warszawa 2006; W. Świerczyńska-Głowania, Działalność programowa telewizji publicznej. Kluczowe determinanty programowania i dystrybucji oferty, Wydawnictwo Uniwersytetu Jagiellońskiego, Kraków 2017; T. Mielczarek, Misja czy komercja - ewolucja programu Telewizji Polskiej SA, „Zeszyty Prasoznawcze” 2013, nr 4, s. 461-476; K. Pokorna-Ignatowicz, Polska telewizja publiczna jako „tup polityczny”, „Studia Medioznaucze” 2010, nr 2, s. 39-47.

2 Zob. m.in.: J. Dzierżyńska-Mielczarek, Rynek mediów w Polsce. Zmiany pod wptywem nowych technologii rynkowych, Oficyna Wydawnicza ASPRA-JR, Warszawa 2018; J. Kreft, Władza algorytmów. U źródeł potęgi Google i Facebooka, Wydawnictwo Uniwersytetu Jagiellońskiego, Kraków 2019. Por. także: S. Gálik, S. Gálikova Tolnaiová, Influence of the Internet on the Cognitive Abilities of Man Phenomenological and Hermeneutical Approach, "Communication Today" 2015, vol. 6, no. 1, p. 7-17.

${ }^{3}$ H.M. Kepplinger, Demontaż polityki w społeczeństwie informacyjnym, przeł. A. Kożuch, Wydaunictuo Uniwersytetu Jagiellońskiego, Kraków 2007, s. 151.

4 Analizy Centrum Badania Opinii Społecznej (CBOS) wykazały w kwietniu 2019 roku, że u stosunku do kwietnia 2017 roku nastąpił 6\% wzrost (z 21\% do 27\%) liczby ankietouanych deklarujących, że informacje o wydarzeniach z kraju i ze świata czerpią przede wszystkim z internetu. Zob. Komunikat z badań nr 70/2019, Wiarygodność mediów, CBOS, Warszawa, maj 2019, s. 1.

${ }^{5}$ Ibidem. 
Celem publikacji jest zatem określenie społecznej oceny trzech głównych nadawców telewizyjnych w Polsce (telewizji publicznej TVP oraz dwóch telewizji komercyjnych TVN i Polsat) jako źródła informacji z uwzględnieniem następujących aspektów:

- uskaźnika aprobaty i dezaprobaty społecznej ich działalności;

- obiektywizmu audycji informacyjnych i publicystycznych;

- wiarygodności ich audycji informacyjnych i publicystycznych.

W związku z tym przyjęto, że wysoki uskaźnik aprobaty społecznej dla poszczególnych telewizji nie jest jednoznaczny z niedostrzeganiem przez odbiorców inklinacji politycznych prezentowanych przez audycje informacyjne i publicystyczne. W publikacji zastosowano następujące metody badawcze: krytyczną analizę literatury, porównawczą, opisową oraz analizę danych zastanych ${ }^{6}$.

\section{O wpływie telewizji}

Kuestia szeroko rozumianego wpłyuu telewizji na świadomość i ocenę rzeczywistości politycznej przez odbiorców nie jest jednoznaczna z tym, że przekaz telewizyjny umożliwia odbiorcy dokonanie rzeczywiście świadomej i zgodnej ze swoimi przekonaniami oceny wydarzeń politycznych oraz aktywności i wypowiedzi polityków. Zdaniem Neila Postmana, na przykład w odniesieniu do wyborów, telewizja wręcz uniemożliwia stuierdzenie,

kto jest od kogo lepszy, jeśli przez «lepszy» rozumiemy coś takiego, jak: zdolniejszy do negocjowania, obdarzony większą wyobraźnią w działaniach praktycznych, bardziej zorientowany w sprawach międzynarodowych, lepiej rozumiejący powiązania między różnymi systemami gospodarczymi i tak dalej. Powód - niemal bez reszty - wiąże się z «obrazem». Nie dlatego jednak, że politycy są zajęci przedstawianiem się $\mathrm{w}$ jak najlepszym świetle. [...] Telewizja jednak przysporzyła obrazowi złej sławy. Ponieważ u telewizji polityk nie tyle ofiarowuje widowni obraz samego siebie, ile proponuje siebie jako obraz w oczach widowni. Na tym właśnie między innymi polega najpotężniejszy upływ reklamy telewizujnej na polityczny dyskurs?

Guy Deborda zuraca uwagę także na zasadniczą rolę telewizji w selekcji, doborze i układzie przekazywanych informacji, co powoduje, że

obraz pod względem technicznym skonstruowany i wybrany przez kogoś innego stał się podstawowym odniesieniem jednostki do świata, [...] w obrębie jednego obrazu można zestawić, bez żadnej sprzeczności, dosłounie byle co. Strumień obrazów uniesie uszystko; kto

\footnotetext{
${ }^{6}$ Przedstawione w publikacji badania CBOS były przeprowadzane metodą wywiadów bezpośrednich (face-to-face) wspomaganych komputerowo (CAPI) na reprezentatyunej próbie losowej dorosłych mieszkańcóu Polski liczącej średnio około 1000 (+/-) osób. Dokładna liczba respondentów dla poszczególnych badań jest podawana w każdym z przytaczanych w publikacji komunikatów CBOS.

${ }^{7}$ N. Postman, Zabawić się na śmierć. Dyskurs publiczny w epoce show-businessu, przeł. L. Niedzielski, Wydaunictuo MUZA, Warszawa 2002, s. 190-191.
} 
inny włada róunież tym uproszczonym streszczeniem świata zmysłowego, decyduje o kierunku tego strumienia oraz nadaje rytm temu, co winno się w nim ukazywać - całkowicie niezależnie od tego, co widz może zrozumieć lub choćby pomyśleć - niczym nieprzerwana, arbitralna niespodzianka, nie pozostawiająca ani chwili na refleksję. [...] Spektakularny dyskurs przemilcza rzecz jasna nie tylko to, co tajne w dosłownym tego słowa znaczeniu, ale róunież uszystko, co mu zawadza. Ukazując zdarzenia, pomija zawsze ich kontekst i ich przeszłość, intencje i konsekwencje ${ }^{8}$.

W podobnym tonie o roli telewizji w funkcjonowaniu państwa i kształtowania poglądów odbiorców wypowiedział się również Giovanni Sartori, który uważa telewizję za jeden

z najpotężniejszych instrumentów kształtowania opinii. Dzisiaj suwerenny naród zazuyczaj «uyraża sądy» w zależności od tego, jaką opinię podpowie mu telewizja. Kierując zaś opiniami, telewizja doprawdy rozciąga swą uładzę nad centrum, gdzie zachodzą uszystkie procesy uspółczesnej polityki ${ }^{9}$.

Tak postrzegana telewizja jest nie tylko zasadniczym kanałem przepływu informacji, lecz także w określonych warunkach może stać się niebezpiecznym instrumentem wpłyuu na nie zawsze świadomych manipulacji obywateli, gdyż - jak stwierdza Hans M. Kepplinger -

wzajemne oddziaływanie między mediami i polityką ma na celu wywarcie upłyuu na aktualny przekaz mediów i jego kształt [...]. Tym niemniej prawie nie można uykazać istnienia takich oddziaływań na podstawie samego przekazu mediów, ponieważ ani politycy, ani dziennikarze nie są zainteresowani tym, żeby u przekazie można było rozpoznać nieformalne układy między nimi ${ }^{10}$.

Jednocześnie nadawcy, bez uzględu na to, jakie preferencje polityczne wykazują, muszą brać pod uwagę przede wszystkim opinie odbiorców, ponieważ to oni

decydują o pozycji mediów na rynku. Oznacza to, że uszystkie media muszą zabiegać o względy odbiorców, tak jak politycy zabiegają o uzględy uyborców. W ostatecznym więc rozrachunku dla mediów i polityków popularność oraz głos opinii publicznej liczą się bardziej niż ideologia czy wartości. To zaś, jak poszczególne media zabiegają o odbiorców i jaki mają stosunek do polityki, zależy od tego, do kogo się zuracają ${ }^{11}$.

Kolejną kwestię stanowi to, że uskazywanie przez respondentów telewizji jako głównego źródła informacji nie oznacza, że uszyscy czy większość odbiorcóu danego przekazu będzie traktować go jako wiarygodny czy istotny. Oczywiście, zaróuno

${ }^{8}$ G. Debord, Społeczeństwo spektaklu oraz Rozważania o społeczeństwie spektakluprzeł. M. Kuaterko, Państwowy Instytut Wydawniczy, Warszawa 2006, s. 167.

${ }_{9}^{9}$ G. Sartori, Homo videns. Telewizja i post-myślenie, przeł. J. Uszyński, Telewizja Polska, Warszawa 2005, s. 38.

${ }^{10}$ H.M. Kepplinger, op. cit., s. 138.

${ }^{11}$ M. Mrozouski, Media masowe. Władza, rozrywka i biznes, Oficyna Wydawnicza ASPRA-JR, Warszawa 2001, s. 132. 
telewizyjne wystąpienia polityków, na co wskazuje Postman, jak i forma i sposób prezentowania informacji przez nadawców i dziennikarzy oraz ich komentarze w znacznym stopniu rzutują na postrzeganie rzeczywistości politycznej i telewizji, niemniej ostateczny efekt skierowanego do obywateli przekazu zależy również od:

- kształtujących postawy bardziej fundamentalnych i truałych czynników osobistych;

- oddziaływania otoczenia społecznego i innych ludzi, którzy mają większy upływ na kształtowanie opinii niż media;

- tendencji ludzi do wybierania źródła informacji i przekazów, z którymi się zgadzają, co prowadzi do utrualania, a nie zmiany poglądów;

- przyczyn zainteresowania przekazem medialnym, gdyż różne motyuy dają różne efekty;

- prezentowania przez media konkurencyjnych poglądów, które uzajemnie się znoszą (np. przy okazji kampanii wyborczych);

- opierania się odbiorców na działania persuazyjne;

- reinterpretacji treści perswazyjnych przez odbiorców ${ }^{12}$.

Tym samym ustalenie bezpośredniego i jednoznacznego wpłyuu telewizji na opinie i postawy odbiorców jest zadaniem trudnym i wymagającym uwzględnienia wielu czynników.

\section{Wskaźnik aprobaty i dezaprobaty działalności stacji telewizyjnych}

Od momentu przekształcenia telewizji państwowej w 1993 roku w telewizję publiczną do 2019 roku Polacy w większości aprobowali jej działalność. Wskaźnik wysokiego poparcia społecznego w ciągu kolejnych lat, z niewielkimi wahnięciami, utrzymywał się stale do 2014 roku, kiedy osiągnął 82\% ${ }^{13}$ (zob. ryciny 1 i 2). Wyraźny spadek akceptacji dla TVP został odnotowany dopiero w marcu 2016 roku, kiedy to aprobatę zadeklarowało 68\% Polaków. Od tego momentu do kwietnia 2017 roku poparcie dla TVP spadło do 55\% ${ }^{14}$. Ponouny, ale niewielki (2\%) wzrost akceptacji nastąpił w październiku 2017 roku i utrzymywał się na zbliżonym poziomie (59\%) do 2018 roku (zob. rycina 2). W 2019 roku aprobata dla nadawcy publicznego ponownie spadła do 57\%.

\footnotetext{
${ }_{12}$ D. McQuail, Teoria komunikowania masowego, przekł. M. Bucholc, A. Szulżycka, Wydawnictwo Naukowe PWN, Warszawa 2008, s. 504.

${ }^{13}$ Komunikat z badań nr 133/2016, Ocena instytucji publicznych, CBOS, Warszawa, wrzesień 2016, s. 17.

${ }^{14}$ Komunikat z badań nr 121/2018, Oceny działalności instytucji publicznych, CBOS, Warszawa, wrzesień 2018, s. 20.
} 


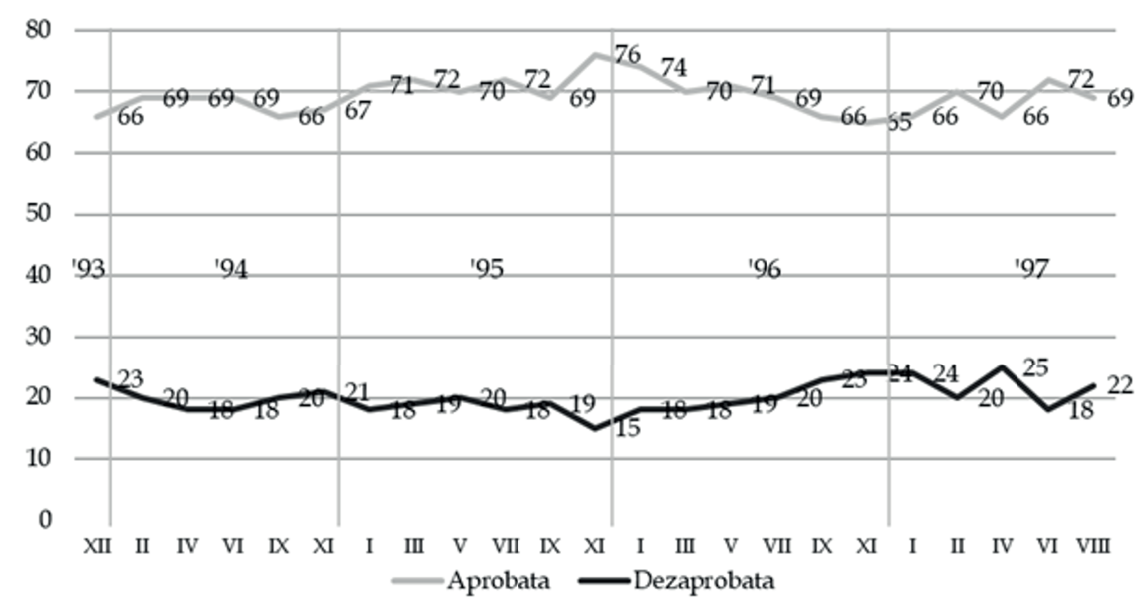

Rycina 1. Ocena społeczna działalności TVP w latach 1993-1997

Źródło: opracowanie ułasne na podstawie: Komunikat z badań nr 113/1997, Ocena działalności instytucji publicznych, CBOS, Warszawa, wrzesień 1997, s. 2, tab. 1; Komunikat z badań nr 179/1995, Zaufanie do instytucji publicznych w czasie wyborów prezydenckich, CBOS, Warszawa, listopad 1995, s. 2, tab. 1; Komunikat z badań nr 39/1994, Opinie o instytucjach publicznych po kryzysie rządowym, CBOS, Warszawa, marzec 1994, s. 2, tab. 1.

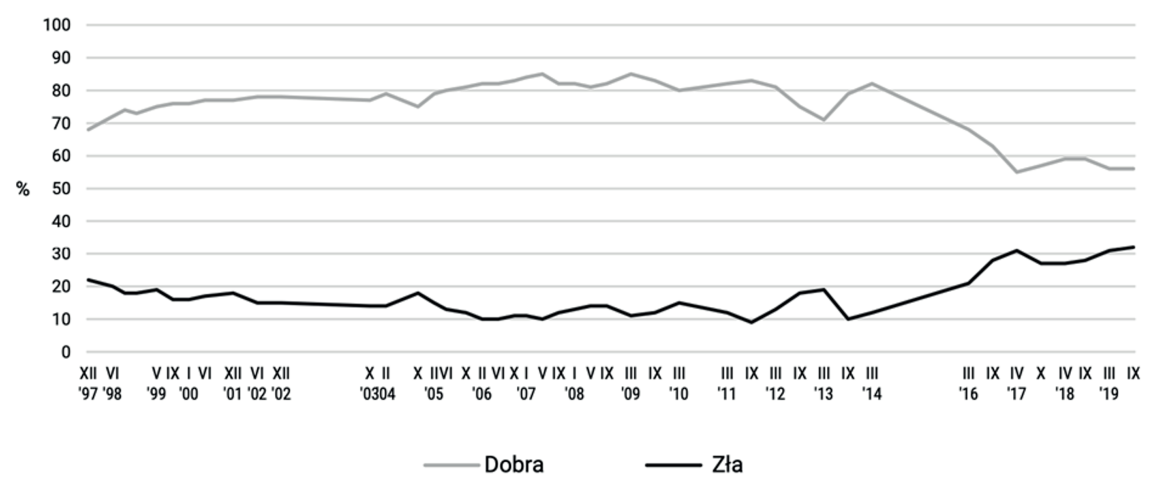

Rycina 2. Ocena społeczna działalności TVP w latach 1997-2019

Źródło: Komunikat z badań nr 118/2019, Ocena działalności instytucji publicznych i mediów, CBOS, Warszawa, urzesień 2019, s. 20.

Również u przypadku nadawców komercyjnych wyraźne obniżenie poziomu akceptacji dla ich działalności nastąpiło w 2016 roku, jednak tylko TVN miał taki sam 14\% - jak TVP (zob. rycina 3). Stacja Polsat odnotowała natomiast 4\% spadek i uzyskała tym samym najwyższy uskaźnik aprobaty (75\%) wśród nadawcóu. Jednocześnie należy zaznaczyć, że w latach 2002-2016 zarówno TVN, jak i Polsat miały zbliżony wysoki uskaźnik poparcia społecznego oscylujący w granicach około 70\%-80\% ${ }^{15}$ (zob. rycing 3

${ }^{15}$ Komunikat z badań nr 118/2019, Ocena działalności instytucji publicznych i mediów, op. cit., s. 20. 
i 4). Znamienne jest również to, że od 2016 roku Polsat utrzymywał pozycję lidera i do 2019 roku miał najuyższy poziom aprobaty społecznej. We wrześniu 2018 roku o jego działalności pozytywnie wypowiedziało się 72\% Polaków, negatyunie zaś 10\%. TVN uzyskał poparcie 65\%, a dezaprobatę 18\% odbiorców. TVP zajęła w tym zestawieniu trzecią pozycję, uzyskując aprobatę 59\% i nie znajdując akceptacji u 28\% ankietowanych.

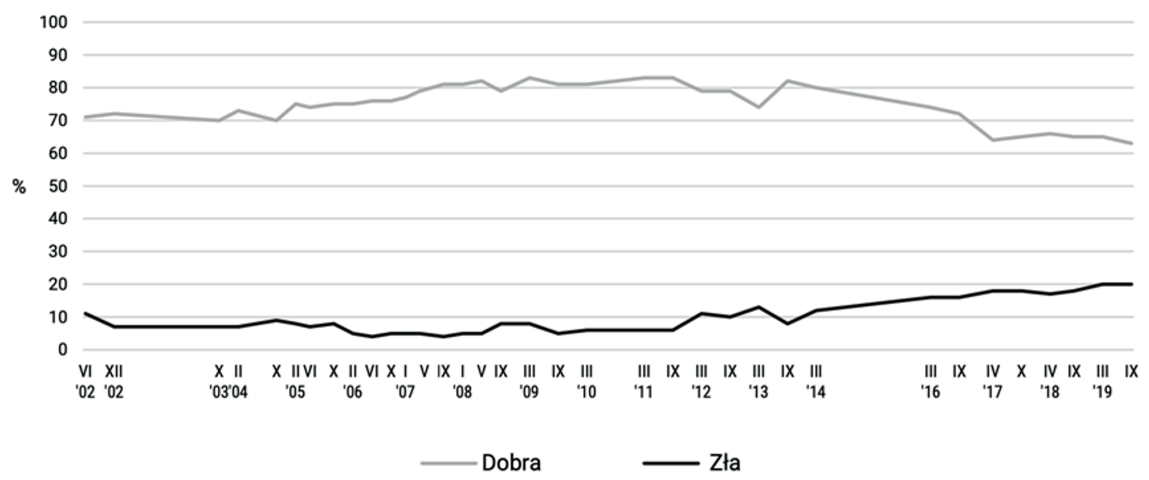

Rycina 3. Ocena społeczna działalności telewizji TVN w latach 2002-2019

Źródło: Komunikat z badań nr 118/2019, Ocena działalności instytucji publicznych i mediów, op. cit., s. 21.

We urześniu 2019 roku pozytyunie o telewizji Polsat wypowiadało się 71\% badanych, a negatywnie $10 \%$

(od marca spadek o 2 punkty procentowe). Działalność TVN dobrze ocenia więcej niż trzy piąte (63\%, spadek o 2 punkty), a źle - jedna piąta (20\%). Bardziej zróżnicowane są opinie o działalności telewizji publicznej, o której z aprobatą wypowiada się ponad połowa Polaków (56\%), a jedna trzecia (32\%) ma do niej zastrzeżenia ${ }^{16}$.

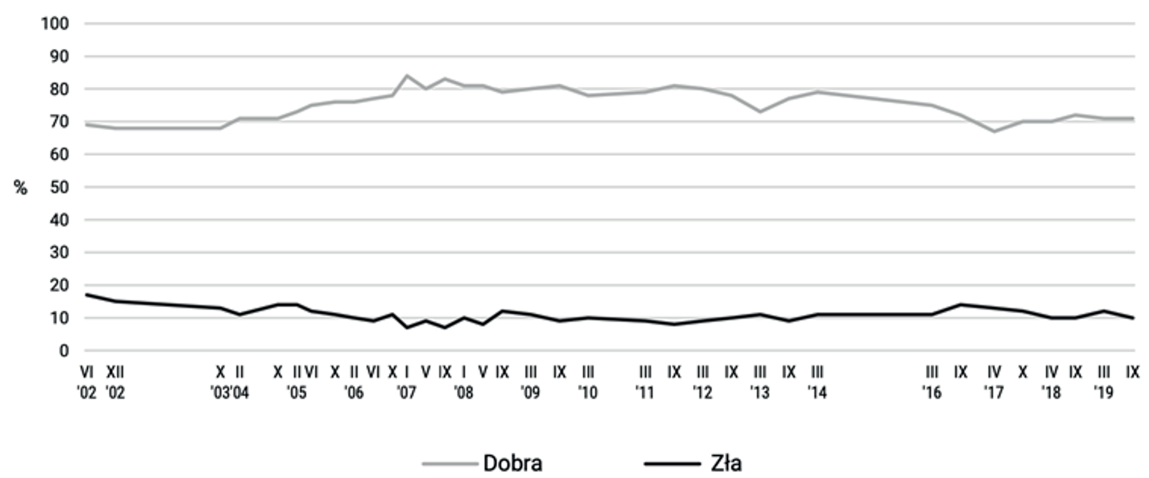

Rycina 4. Ocena społeczna działalności telewizji Polsat w latach 2002-2019

Źródło: Komunikat z badań nr 118/2019, Ocena działalności instytucji publicznych i mediów, op. cit., s. 21.

${ }_{16}$ Ibidem. 
Spadkowi akceptacji dla TVP towarzyszyło zdecydowane obniżenie poziomu oglądalności telewizji publicznej, zwłaszcza głównych programów informacyjnych. Zaistniałą sytuację Stanisław Mocek łączy ze sporem politycznym wokół mediów publicznych. Zauważył, że „w okresie nowelizacji ustawy o radiofonii i telewizji (przełom 2015 i 2016 roku) segment rynku telewizyjnego w Polsce przedstawiał się następująco: publiczna telewizja TVP 1 (945 tys. średniej oglądalności) i TVP 2 (636 tys.) i TVP INFO (286 tys.), komercyjne: Polsat (816 tys.) i TVN (769 tys.) [.... Ale już w czerwcu 2017 roku nastąpiła uyrá́na zmiana: publiczna telewizja TVP 1 (506 tys. średniej oglądalności) i TVP 2 (359 tys.) i TVP INFO (223 tys.), komercyjne: Polsat (622 tys.) i TVN (509 tys.). Jeszcze bardziej znaczące różnice zachodziły w widouni stacji publicznych w przedziale wieku od 16 do 49 lat" ${ }^{\prime 17}$. W roku 2018 i 2019 program Polsat nadal był liderem oglądalności, TVP 1 zajęło drugą pozycję, a TVN trzecią (zob. tabela 1).

Tabela 1. Poziom oglądalności programów telewizyjnych w 2018 i 2019 roku

\begin{tabular}{|c|c|c|}
\hline \multicolumn{3}{|c|}{20 najpopularniejszych kanałów TV w Pols } \\
\hline Lp. $\mid$ Stacja & 2018 & 2019 \\
\hline 1|Polsat & $10,23 \%$ & $9,85 \%$ \\
\hline 2 TVP1 & $9,73 \%$ & $9,68 \%$ \\
\hline $3 / T V N$ & $9,38 \%$ & $8,45 \%$ \\
\hline $\begin{array}{l}4 \longdiv { T V P 2 } \\
\end{array}$ & $8,16 \%$ & $8,34 \%$ \\
\hline \begin{tabular}{l|l} 
TVN24 \\
\end{tabular} & $4,14 \%$ & $4,47 \%$ \\
\hline \begin{tabular}{l|l}
6 TV4 \\
\end{tabular} & $4,16 \%$ & $3,72 \%$ \\
\hline \begin{tabular}{l|l|l|}
7 TVPINFO \\
\end{tabular} & $3,43 \%$ & $3,64 \%$ \\
\hline 8 TV PULS & $3,40 \%$ & $3,50 \%$ \\
\hline 9 TVN7 & $3,24 \%$ & $3,21 \%$ \\
\hline \begin{tabular}{l|l|l|}
$10 T V$ \\
\end{tabular} & $2,14 \%$ & $2,24 \%$ \\
\hline \begin{tabular}{l|l}
11 & Puls 2
\end{tabular} & $1,88 \%$ & $1,91 \%$ \\
\hline \begin{tabular}{l|l|}
12 & TV6 \\
\end{tabular} & $1,45 \%$ & $1,70 \%$ \\
\hline 13|Polsat2 & $1,52 \%$ & $1,54 \%$ \\
\hline $\begin{array}{l}14 \\
\text { TVP Seriale } \\
\end{array}$ & $1,41 \%$ & $1,41 \%$ \\
\hline 15 TVPABC & $1,39 \%$ & $1,28 \%$ \\
\hline \begin{tabular}{l|l|l|}
16 & TVP Sport \\
\end{tabular} & $0,97 \%$ & $1,25 \%$ \\
\hline 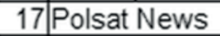 & $1,12 \%$ & $1,13 \%$ \\
\hline \begin{tabular}{|l|l|}
18 Stopklatka \\
\end{tabular} & $0,98 \%$ & $1,12 \%$ \\
\hline 19|TVP3 & $0,89 \%$ & $1,02 \%$ \\
\hline \begin{tabular}{l|l|}
20 Super Polsat \\
\end{tabular} & $0,94 \%$ & $0,94 \%$ \\
\hline
\end{tabular}

Źródło: Telewizję w 2019 roku oglądaliśmy krócej. Królował Polsat, ale TVP ma też powód do zadowolenia, https://businessinsider.com.pl/media/tv-radio/ogladalnosc-telewizji-w-2019-roku-dane-nielsena/ffuwf89 (dostęp: 19.08.2020).

17 S. Mocek, Władza i media. Dyskurs polityczny wokót mediów publicznych w Polsce, „Zoon Politikon” 2017, nr 8, s. 38-39, https://wuw.civitas.edu.pl/wp-content/uploads/2015/03/ ZP_08_2017_033-060.pdf (dostęp: 19.08.2020). 


\section{Obiektywizm i wiarygodność audycji informacyjnych i publicystycznych}

Pomimo spadku akceptacji i oglądalności TVP (w porównaniu do okresu sprzed 2014 roku) to audycje informacyjne i publicystyczne nadawcy publicznego respondenci najczęściej wskazywali w 2019 roku jako ich główne źródła codziennych informacji o wydarzeniach w kraju i na świecie (zob. rycina 5). Z przedstawionych przez CBOS

analiz wynika, że wybór określonej stacji telewizyjnej zależy przede uszystkim od poglądów politycznych i preferencji partyjnych. Programy TVN oraz TVN24 częściej niż pozostali uybierają badani identyfikujący się z lewicą, programy telewizyjnej Jedynki oraz TVP Info - respondenci utożsamiający się z prawicą, a Wydarzenia i inne programy Polsatu ankietowani o poglądach centrowych. W potencjalnych elektoratach partyjnych programy informacyjne TVN częściej wybierają wyborcy PO i PSL, a TVN24 - wyborcy PO. Z kolei na programy u telewizji publicznej najczęściej decydują się zwolennicy PiS. Natomiast Wydarzenia i inne programy Polsatu równie często uybierane są przez zuolenników PiS i PO, a relatywnie najczęściej przez sympatyków ruchu Kukiz’15 i Wiosny ${ }^{18}$.

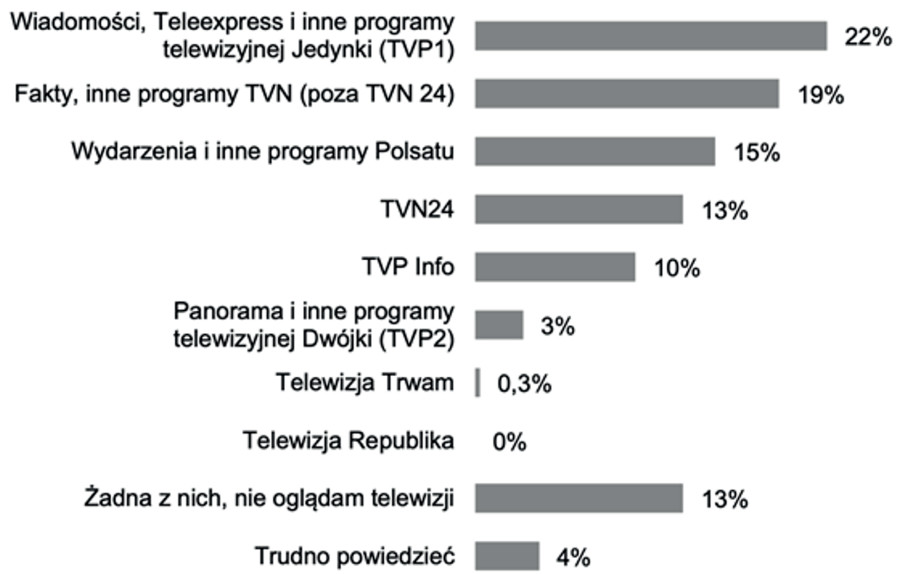

Rycina 5. Główne źródła informacji Polaków o wydarzeniach w kraju i na świecie w 2019 roku Źródło: Komunikat z badań nr 70/2019, Wiarygodność mediów, CBOS, Warszawa, maj 2019, s. 4.

Odbiorcy u poszukiwaniu wiadomości nie ograniczali się jednak do jednego źródła informacji. Z przeprowadzonych badań wynika, że 63\% badanych oglądało audycje TVP, 62\% TVN, a 57\% Polsatu (zob. rycina 6), a zatem świadomie podejmowali próbę weryfikacji prezentowanych im treści. Należy też zauważyć, iż różnica w deklarowanej łącznej oglądalności programów TVP i telewizji Polsat wynosiła tylko 1\%.

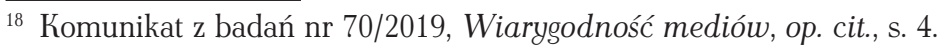




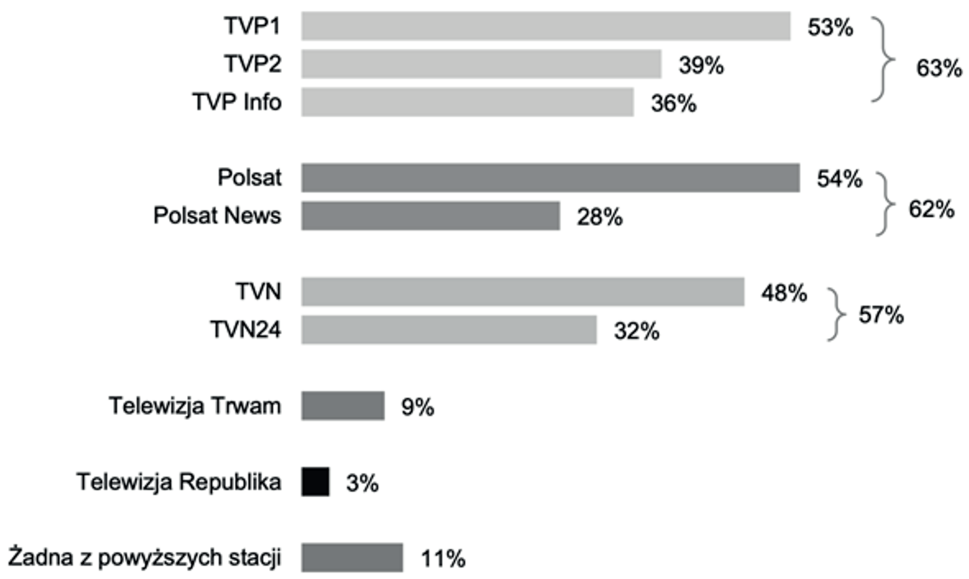

Rycina 6. Wszystkie programy telewizyjne, których audycje informacyjne i publicystyczne oglądali odbiorcy u 2019 roku

Źródło: Komunikat z badań nr 70/2019, Wiarygodność mediów, op. cit., s. 3.

Wynik ten koresponduje z rezultatami uzyskanymi w 2015 roku przez zespół badawczy kierowany przez Jana Garlickiego, który ustalił, że 98\% badanych w ramach projektu osób oglądało telewizję, przy czym korzystali oni z różnych typów stacji, zarówno publicznych, jak i komercyjnych oraz w mniejszym stopniu społecznych i tematycznych (zob. rycina 7). Zaobserwowano też, że chociaż respondenci oglądali przekazy wielu stacji, występowały w ich deklaracjach preferencje

względem jednego programu informacyjnego, jednak nie oznacza to korzystania wyłącznie z tego programu. [...] W telewizji treści informacyjne najczęściej czerpane są z wieczornych programów informacyjnych. Można zaobserwować tendencję do porównywania ich między sobą i oglądania ich ug kolejności emisji - «Wydarzenia» (Polsat), «Fakty» (TVN), «Wiadomości» (TVP1) $)^{19}$.

${ }^{19}$ Raport całościowy z badania: Różnorodność treści informacyjnych w Polsce z perspektywy użytkownika, red. J. Garlicki, Warszawa 2015, s. 25, http:/wuw.krrit.gov.pl/Data/ Files/_public/Portals/0/publikacje/analizy/roznorodnosc-tresci-informacyjnych-w-polsce.pdf (dostęp: 12.08.2020). 


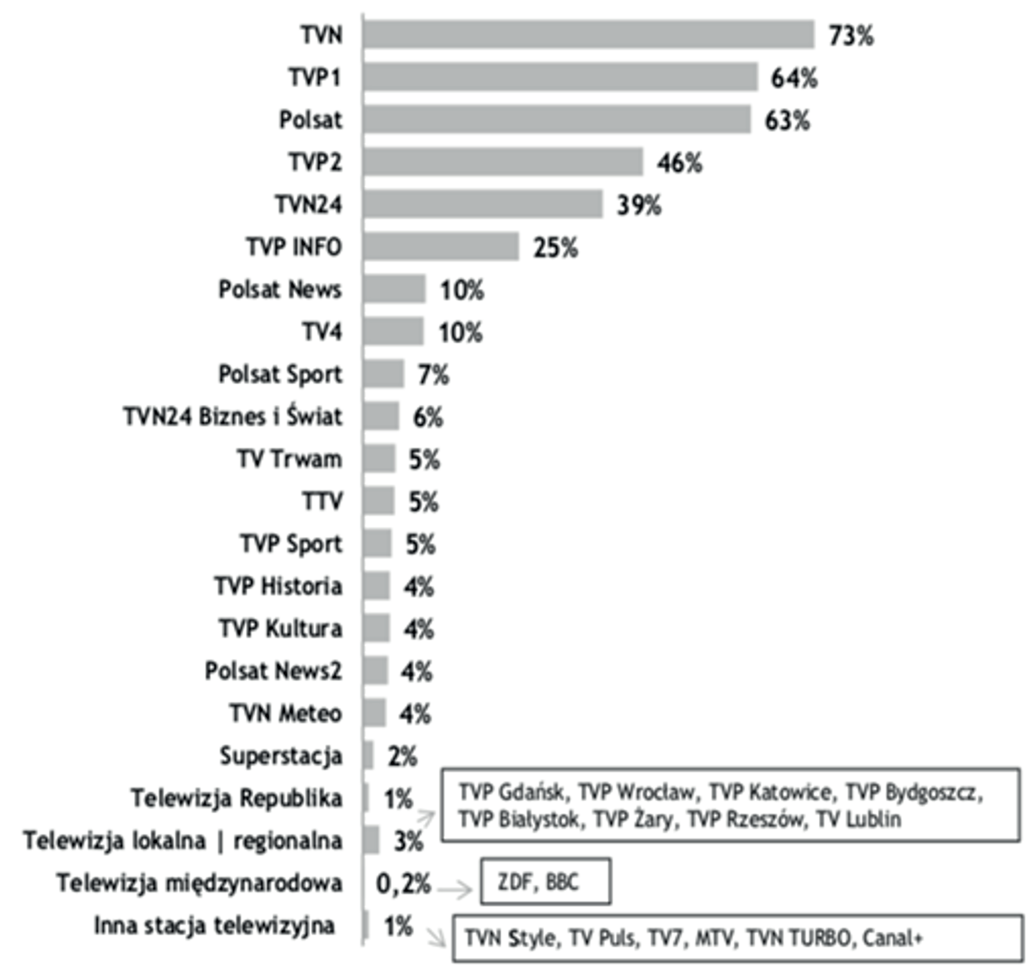

Rycina 7. Najczęściej oglądane telewizyjne źródła informacji w 2015 roku

Źródło: Raport całościowy z badania: Różnorodność treści informacyjnych w Polsce z perspektywy użytkownika, red. J. Garlicki, op. cit., s. 23.

Poróunywanie audycji informacyjnych może, z jednej strony, wynikać z przenikania się paradygmatu telewizji komercyjnej z publiczną, na co zwrócił uwagę Stanisław Jędrzejeuski. Konsekwencją tego stanu rzeczy jest zachodzenie na siebie audytoriów obu modeli telewizji, następnie zaś „kontrowersjami wokół sposobów pomiaru audytoriów obyduu typów instytucji oraz miar efektywności ich działania, ergo: kontrowersjami wobec wiedzy instytucjonalnej obyduu typów mediów" ${ }^{20}$.

$\mathrm{Z}$ drugiej strony istotne $\mathrm{u}$ tym kontekście są deklaracje respondentów CBOS, z których wynika, że zdaniem 56\% badanych większość mediów nie zachowywała bezstronności, a 92\% ankietowanych zgadzało się ze stuierdzeniem: „aby wyrobić sobie zdanie na temat bieżących wydarzeń, należy korzystać z różnych źródeł informacji”. Odpowiedzi uskazują też, że Polacy czuli się zdezorientowani i na podstawie tak różnych przekazów medialnych nie byli u stanie określić „gdzie leży prauda” (zob. rycina 8).

${ }^{20}$ S. Jędrzejewski, Wiedza o audytorium mediów a możliwości jego kontroli [w:] Teorie komunikacji i mediów, red. M. Graszewicz, J. Jastrzębski, t. 1, Oficyna Wydawnicza ATUT, Wrocław 2009, s. 146. 


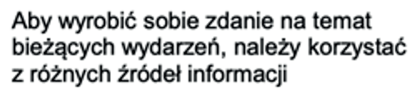

Przekaz w różnych mediach na temat tych samych wydarzeń jest tak różny, że nie wiadomo, gdzie leży prawda

Większość mediów w Polsce zachowuje bezstronność

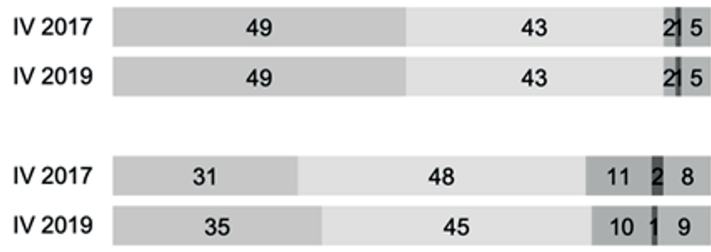

\begin{tabular}{|l|l|l|l|l|l|}
\hline IV 2017 & 5 & 27 & 40 & 13 & 15 \\
\hline IV 2019 & 5 & 22 & 42 & 14 & 17 \\
\hline
\end{tabular}

घ Zdecydowanie się nie zgadzam
= Trudno powiedzieć

Rycina 8. Opinie na temat bezstronności przekazów medialnych

Źródło: Komunikat z badań nr 70/2019, Wiarygodność mediów, op. cit., s. 15.

Uwzględniając opinie Polaków na temat akceptacji dla działalności stacji telewizyjnych, tendencje w oglądalności poszczególnych programów oraz stosunek do bezstronności mediów jako takich, należy zwrócić uwagę na ocenę telewizujnych programów informacyjnych i publicystycznych (rycina 9). Z badań CBOS z lat 2006, 2012, 2017 i 2019 dotyczących oceny preferencji politycznych oraz wiarygodności tych audycji wynika, że odbiorcy mieli świadomość, iż przekazywane im treści charakteryzowało określone zabarwienie polityczne związane z preferencjami politycznymi nadawcó $w^{21}$. O ile jednak w przypadku mediów komercyjnych i społecznych nie jest to w żaden sposób regulowane, o tyle w odniesieniu do mediów publicznych w art. 21 ust. 2 pkt 2 Ustawy z dnia 29 grudnia 1992 roku o radiofonii i telewizji stwierdzono, że programy powinny „rzetelnie ukazywać całą różnorodność wydarzeń i zjawisk w kraju i za granicą".

${ }^{21}$ Szerzej o inklinacjach politycznych w telewizyjnych audycjach informacyjnych piszą m.in.: D. Piontek, Komunikowanie polityczne i kultura popularna. Tabloidyzacja informacji o polityce, Wydaunictwo Naukowe WNPiD UAM, Poznań 2011, s. 203-207; E. Nowak-Teter, Rodzaje i przejawy tendencyjności $w$ telewizyjnych programach informacyjnych $w$ Polsce, ,e-Politikon” 2017, nr 21, s. 102-133, http://oapuw.pl/wp-content/uploads/2017/07/ePolitikon-21-2017.pdf (dostęp: 23.08.2020); R. Klepka, Ewolucja Wiadomości TVP1: od medialnej stronniczości do propagandy politycznej? [w:] Walka informacyjna. Uwarunkowania - Incydenty - Wyzwania, red. H. Batorouska, Uniwersytet Pedagogiczny im. Komisji Edukacji Narodowej u Krakowie, Instytut Bezpieczeństwa i Edukacji Obywatelskiej, Katedra Kultury Informacyjnej i Zarządzania Informacją, Kraków 2017, s. 244-251. 


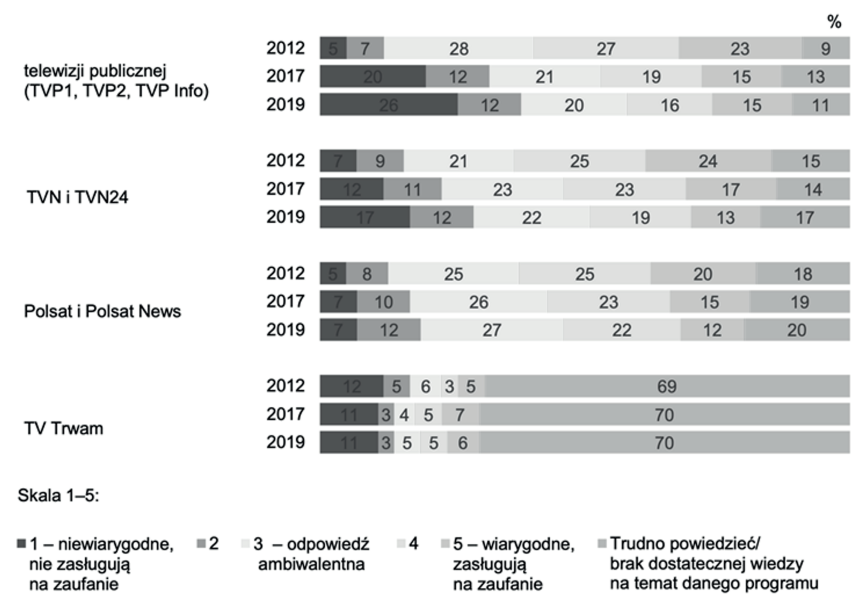

Rycina 9. Ocena wiarygodności telewizyjnych programów informacyjnych i publicystycznych Źródło: Komunikat z badań nr 70/2019, Wiarygodność mediów, op. cit., s. 5.

Druga istotna kwestia, która jest ściśle związana z postrzeganiem obiektywizmu i wiarygodności audycji informacyjnych i publicystycznych to podawanie przez media informacji od razu razem z ich interpretacją (rycina 10). Zdaniem 59\% badanych (w 2019 roku nastąpił spadek o 5 punktów procentowych w stosunku do 2017 roku) „obecnie dziennikarze zamiast informować, wyrażają własne poglądy, a niespełna co czwarty jest przeciunego zdania (23\%, spadek o 2 punkty)"22.
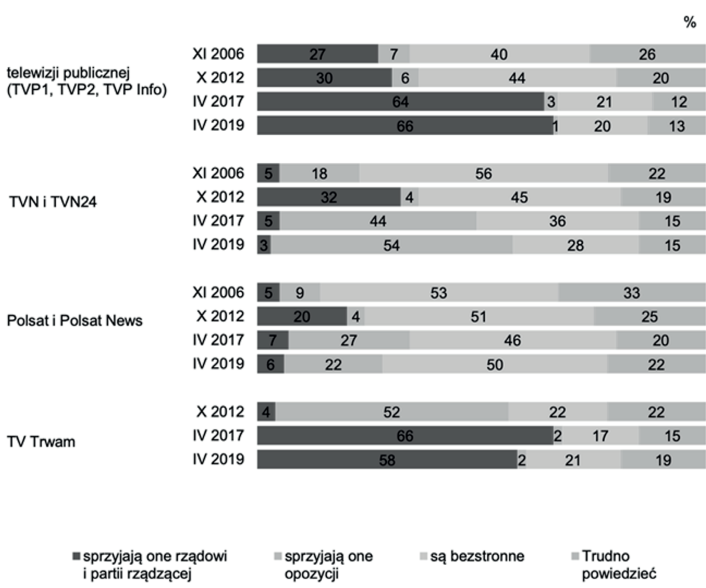

* Treść pytania z roku 2006 nieznacznie się różniła. Pytaliśmy o nastawienie polityczne programów informacyjnych i publicystycznych telewizji publicznej, TVN oraz telewizji Polsat. W latach 2006 i 2012 jedna z odpowiedzi na pytanie brzmiała: "sprzyjają one rządowi i koalicji rządzącej"

Wyłączone zostały odpowiedzi badanych nieoglądających poszczególnych stacji telewizyjnych

Rycina 10. Ocena społeczna obiektywizmu głównych programów telewizyjnych Źródło: Komunikat z badań nr 70/2019, Wiarygodność mediów, op. cit., s. 9.

${ }^{22}$ Komunikat z badań nr 70/2019, Wiarygodność mediów, op. cit., s. 15. 
Jednym z istotnych i niepokojących ustaleń wynikających z deklaracji Polaków na temat mediów i rzeczywistości politycznej jest także łączenie tych dwóch przestrzeni z mową nienawiści. Z deklaracji ankietowanych wynika, że 57\% z nich z wypowiedziami o tym charakterze spotkało się w telewizji, jest to drugie - po internecie (65\%) - wskazywane najczęściej przez respondentów miejsce. Zdaniem respondentów najczęściej mowę nienawiści stosowali użytkownicy sieci (55\%), co ściśle łączy się z ucześniejszym stwierdzeniem na temat obecności hejtu u internecie. Na drugim miejscu zostali wymienieni politycy (47\%), a na szóstym dziennikarze, publicyści i prezenterzy (20\%). Ponadto w badaniach wskazani zostali także: zuykli ludzie w miejscach publicznych (44\%), uczestnicy demonstracji, protestów, marszów (35\%), członkowie skrajnych organizacji społecznych (29\%), artyści i osoby z branży rozrywkowej (9\%), przedstawiciele Kościoła rzymskokatolickiego, księża (8\%), osoby z bliskiego otoczenia - znajomi, rodzina (7\%), uspółpracounicy i przełożeni (6\%) oraz osoby ze świata nauki (1\%) ${ }^{23}$. Tak wysoka pozycja telewizji i polityków w tych wskazaniach kładzie się cieniem na kondycję i jakość dyskursu politycznego toczonego za pośrednictuem i z udziałem telewizji jako aktora politycznego, którego reprezentują przecież dziennikarze i publicyści.

\section{Podsumowanie}

Przedstawione wyniki badań wyraźnie wskazują na kilka kwestii. Przede uszystkim telewizja pozostaje dla Polaków głównym źródłem informacji na temat wydarzeń w kraju i na świecie, pomimo sukcesywnego i wyraźnego spadku (od 2016 roku) aprobaty dla działalności trzech największych stacji telewizyjnych. Ponadto Polacy wykazywali wysoki poziom aprobaty dla działalności nadawców, mając świadomość, że ich audycje oraz programy informacyjne i publicystyczne prezentują treści preferujące określone opcje polityczne, co pozwala pozytyunie zueryfikować postawioną hipotezę. Występuje też uyraźna korelacja między spadkiem aprobaty a uzrostem zaangażowania prezentowanych audycji $\mathrm{w}$ polaryzację polskiej sceny politycznej, co ukazują zdecydowanie większe spadki akceptacji w przypadku TVP i TVN. Stacja Polsat, która odnotowała najniższe spadki w tym zakresie, uzyskała też dla swoich programów najuyższe uskaźniki wiarygodności i obiektywizmu.

Niepokojącym zjawiskiem jest dezorientacja odbiorców deklarujących (80\%), iż przekazy medialne powodują, że „nie wiedzą, gdzie leży prawda”. Zbyt duża dezorientacja u tym zakresie może bowiem powodować zniechęcenie respondentów do odbioru informacji i pogłębiania swojej wiedzy na temat rzeczywistości politycznej, co u konsekwencji może rzutować na aktywność polityczną obywateli. Pozytywnym aspektem tej dezorientacji jest konfrontowanie i weryfikowanie uzyskiwanych przez respondentów informacji w przekazach różnych nadawców.

Ponadto należy zwrócić uwagę na wysokie uskaźniki sygnalizujące brutalizację wypowiedzi polityków oraz dziennikarzy w przekazach telewizyjnych. Traktując

${ }^{23}$ Komunikat z badań nr 139/2019, Mowa nienawiści, CBOS, Warszawa, listopad 2019, s. 7. 
telewizję jako głóuny nośnik treści informacyjnych i publicystycznych, należy postulować merytoryczność dyskursu politycznego, a napiętnować i niwelować wypowiedzi i wystąpienia mające charakter czy znamiona mowy nienawiści, ataków ad personam czy ad ridiculum.

\section{Bibliografia}

Bourdieu P., O telewizji. Panowanie dziennikarstwa, przeł. K. Sztandar-Sztanderska, A. Ziółkouska, Wydaunictuo Naukoue PWN, Warszawa 2009.

Briggs M., Telewizja i jej odbiorcy w życiu codziennym, przeł. B. Radwan, Wydawnictwo Uniwersytetu Jagiellońskiego, Kraków 2012.

Debord G., Spoteczeństwo spektaklu oraz Rozważania o spoteczeństwie spektaklu, przeł. M. Kuaterko, Państuouy Instytut Wydawniczy, Warszawa 2006.

Dobek-Ostrouska B., Polski system medialny na rozdrożu. Media w polityce, polityka w mediach, Wydawnictwo Uniwersytetu Wrocłauskiego, Wrocław 2011.

Dzierżyńska-Mielczarek J., Rynek mediów w Polsce. Zmiany pod wpływem nowych technologii rynkowych, Oficyna Wydawnicza ASPRA-JR, Warszawa 2018.

Gálik S., Gálikova Tolnaiová S., Influence of the Internet on the Cognitive Abilities of Man Phenomenological and Hermeneutical Approach, „Communication Today” 2015, vol. 6, no. 1 , p. $7-17$.

Hellueg S.A., Pfau M., Brydon S.R., Televised Presidential Debates: Advocacy in Contemporary America, Praeger Publishers, New York 1992.

Jaskiernia A., Od telewizji masowej do Netfliksa. Telewizja w Stanach Zjednoczonych w epoce cyfrowej, Oficyna Wydawnicza ASPRA-JR, Warszawa 2016.

Jędrzejeuski S., Wiedza o audytorium mediów a możliwości jego kontroli [u:] Teorie komunikacji i mediów, red. M. Graszewicz, J. Jastrzębski, t. 1, Oficyna Wydaunicza ATUT, Wrocław 2009.

Kepplinger H.M., Demontaż polityki w społeczeństwie informacyjnym, przeł. A. Kożuch, Wydawnictwo Uniwersytetu Jagiellońskiego, Kraków 2007.

Klepka R., Ewolucja Wiadomości TVP1: od medialnej stronniczości do propagandy politycznej? [w:] Walka informacyjna. Uwarunkowania - Incydenty - Wyzwania, red. H. Batorouska, Uniwersytet Pedagogiczny im. Komisji Edukacji Narodowej w Krakowie, Instytut Bezpieczeństua i Edukacji Obywatelskiej, Katedra Kultury Informacyjnej i Zarządzania Informacją, Kraków 2017.

Komunikat z badań nr 39/1994, Opinie o instytucjach publicznych po kryzysie rządowym, CBOS, Warszawa, marzec 1994.

Komunikat z badań nr 70/2019, Wiarygodność mediów, CBOS, Warszawa, maj 2019.

Komunikat z badań nr 113/1997, Ocena działalności instytucji publicznych, CBOS, Warszawa, urzesień 1997.

Komunikat z badań nr 118/2019, Ocena działalności instytucji publicznych i mediów, CBOS, Warszawa, wrzesień 2019.

Komunikat z badań nr 121/2018, Oceny działalności instytucji publicznych, CBOS, Warszawa, wrzesień 2018.

Komunikat z badań nr 133/2016, Ocena instytucji publicznych, CBOS, Warszawa, urzesień 2016. 
Komunikat z badań nr 179/1995, Zaufanie do instytucji publicznych w czasie wyborów prezydenckich, CBOS, Warszawa, listopad 1995.

Kreft J., Władza algorytmów. U źródet potęgi Google i Facebooka, Wydaunictuo Uniwersytetu Jagiellońskiego, Kraków 2019.

McQuail D., Teoria komunikowania masowego, przekł. M. Bucholc, A. Szulżycka, Wydawnictwo Naukowe PWN, Warszawa 2008.

Mielczarek T., Misja czy komercja - ewolucja programu Telewizji Polskiej SA, „Zeszyty Prasoznaucze" 2013, nr 4, s. 461-476.

Mocek S., Władza i media. Dyskurs polityczny wokół mediów publicznych w Polsce, „Zoon Politikon" 2017, nr 8, s. 33-57, https://www.civitas.edu.pl/wp-content/uploads/2015/03/ ZP_08_2017_033-060.pdf (dostęp: 19.08.2020).

Mrozouski M., Media masowe. Władza, rozrywka i biznes, Oficyna Wydawnicza ASPRA-JR, Warszawa 2001.

Nowak-Teter E., Rodzaje i przejawy tendencyjności w telewizyjnych programach informacyjnych w Polsce, ,e-Politikon” 2017, nr 21, s. 102-133, http://oapuw.pl/wp-content/ uploads/2017/07/ePolitikon-21-2017.pdf (dostęp: 23.08.2020).

Ociepka B., Dla kogo telewizja? Model publiczny w postkomunistycznej Europie Środkowej, Wydawnictwo Uniwersytetu Wrocłauskiego, Wrocłau 2003.

Piontek D., Komunikowanie polityczne i kultura popularna. Tabloidyzacja informacji o polityce, Wydawnictuo Naukowe WNPiD UAM, Poznań 2011.

Pokorna-Ignatowicz K., Polska telewizja publiczna jako „tup polityczny”, „Studia Medioznawcze" 2010, nr 2, s. 39-47.

Postman N., Zabawić się na śmierć. Dyskurs publiczny w epoce show-businessu, przeł. L. Niedzielski, Wydawnictuo MUZA, Warszawa 2002.

Raport całościowy z badania: Różnorodność treści informacyjnych w Polsce z perspektywy użytkownika, red. J. Garlicki, Warszawa 2015, http://www.krrit.gov.pl/Data/Files/_public/ Portals/0/publikacje/analizy/roznorodnosc-tresci-informacyjnych-u-polsce.pdf (dostęp: 12.08.2020).

Sartori G., Homo videns. Telewizja i post-myślenie, przeł. J. Uszyński, Telewizja Polska, Warszawa 2005.

Świerczyńska-Głowania W., Działalność programowa telewizji publicznej. Kluczowe determinanty programowania i dystrybucji oferty, Wydawnictwo Uniwersytetu Jagiellońskiego, Kraków 2017.

Television and the Public Interest. Vulnerable Values in West European Broadcasting, red. J.G. Blumler, SAGE Publications, London 1992.

Television News Research: Recent European Approaches and Findings, red. K. Renckstorf, D. McQuail, N. Jankouski, Quintessence Publishing Deutschland, Berlin 2001.

Telewizje w 2019 roku oglądaliśmy krócej. Królowat Polsat, ale TVP ma też powód do zadowolenia, https://businessinsider.com.pl/media/tv-radio/ogladalnosc-telewizji-u-2019-roku-dane-nielsena/ffuwf89 (dostęp: 19.08.2020).

Toeplitz K.T., Dokąd prowadza nas media, Wydawnictuo Iskry, Warszawa 2006. 